\title{
Impoundment and Baldcypress Swamp Management
}

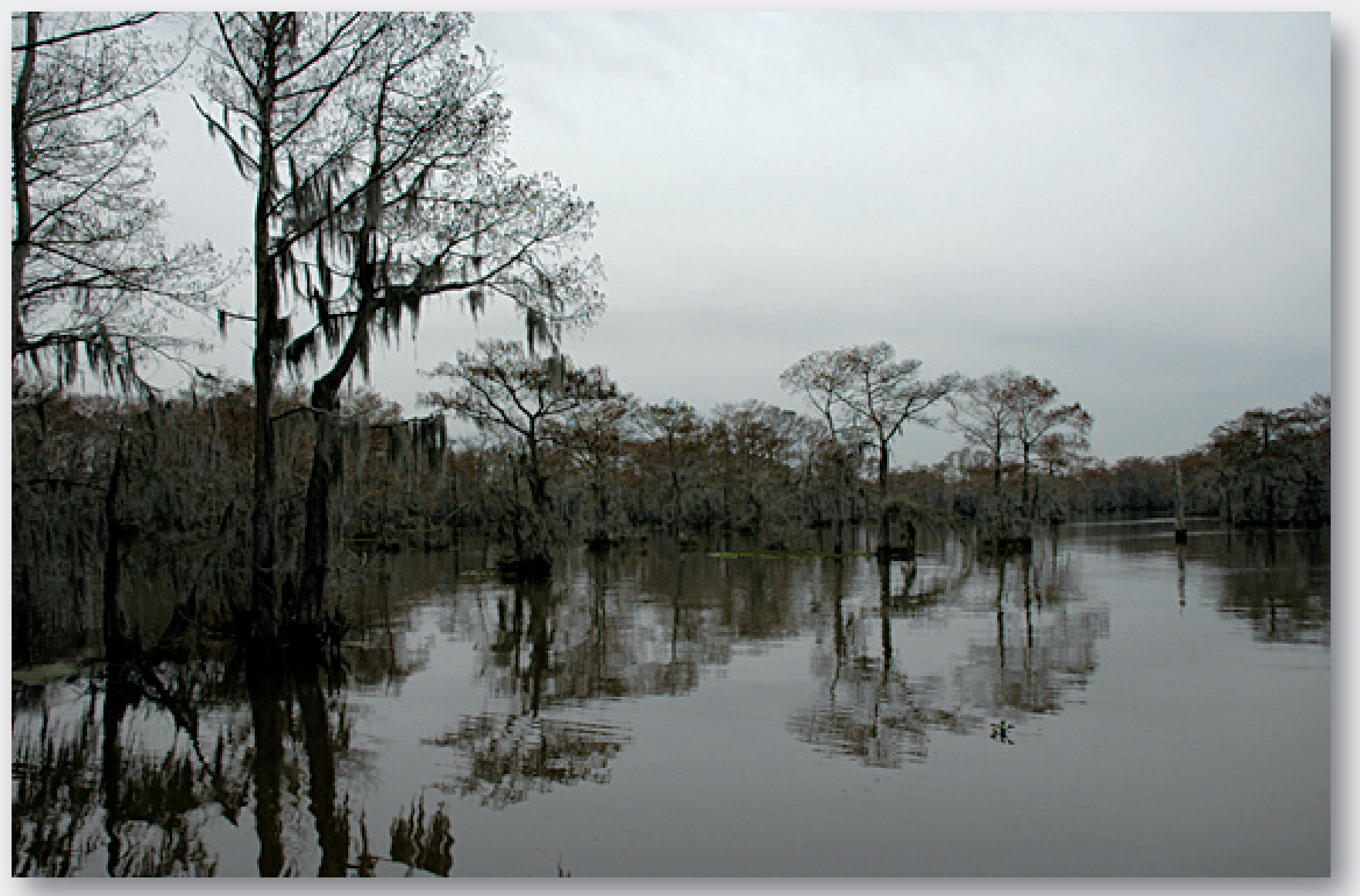

Open-File Report 2006-1270 


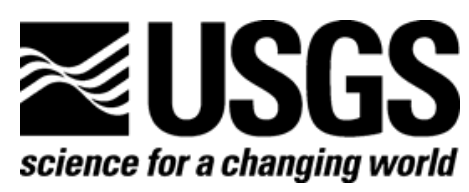

\title{
Impoundment and Baldcypress Swamp Management
}

\author{
By Beth A. Middleton
}

Open-File Report 2006-1270

U.S. Department of the Interior U.S. Geological Survey 


\section{U.S. Department of the Interior \\ DIRK KEMPTHORNE, Secretary}

\section{U.S. Geological Survey \\ P. Patrick Leahy, Acting Director}

U.S. Geological Survey, Reston, Virginia 2006

For product and ordering information:

World Wide Web: http://www.usgs.gov/pubprod

Telephone: 1-888-ASK-USGS

For more information on the USGS - the Federal source for science about the Earth, its natural and living resources, natural hazards, and the environment:

World Wide Web: http://www.usgs.gov

Telephone: 1-888-ASK-USGS

Suggested citation:

Middleton, B.A., 2006, Impoundment and baldcypress swamp management: U.S. Geological Survey Open-File Report 2006-1270, 4 p.

Any use of trade, product, or firm names is for descriptive purposes only and does not imply endorsement by the U.S. Government. 


\title{
Impoundment and Baldcypress Swamp Management
}

\author{
By Beth A. Middleton'
}

Baldcypress swamps (Taxodium distichum) are impounded for many reasons, but this practice results in the demise of the swamp. The permanent impoundment of baldcypress swamps first lowers primary production and eventually results in death of the trees (Fig. 1; Penfound, 1949; Eggler and Moore, 1961; Harms and others, 1980; Conner and Day, 1988, 1992; Heitmeyer and others, 1989; Loftus, 1994; Osment-DeLoach and Moore, 1996).

Individuals of most species die if they are flooded continuously above the root collar for 1 to 6 years (Yeager, 1949). The most likely cause of death and low production in impounded conditions is the low available oxygen levels in the tree roots, where the carbohydrate reserves are stored (Harms and others, 1980). Trees begin to show decline when the major growth regions of the trees are near the trunk and not near the branch tips (Klimas, 1987). Managers should avoid impounding baldcypress swamps for long periods of time because of the relationship of tree death to long-term flooding.

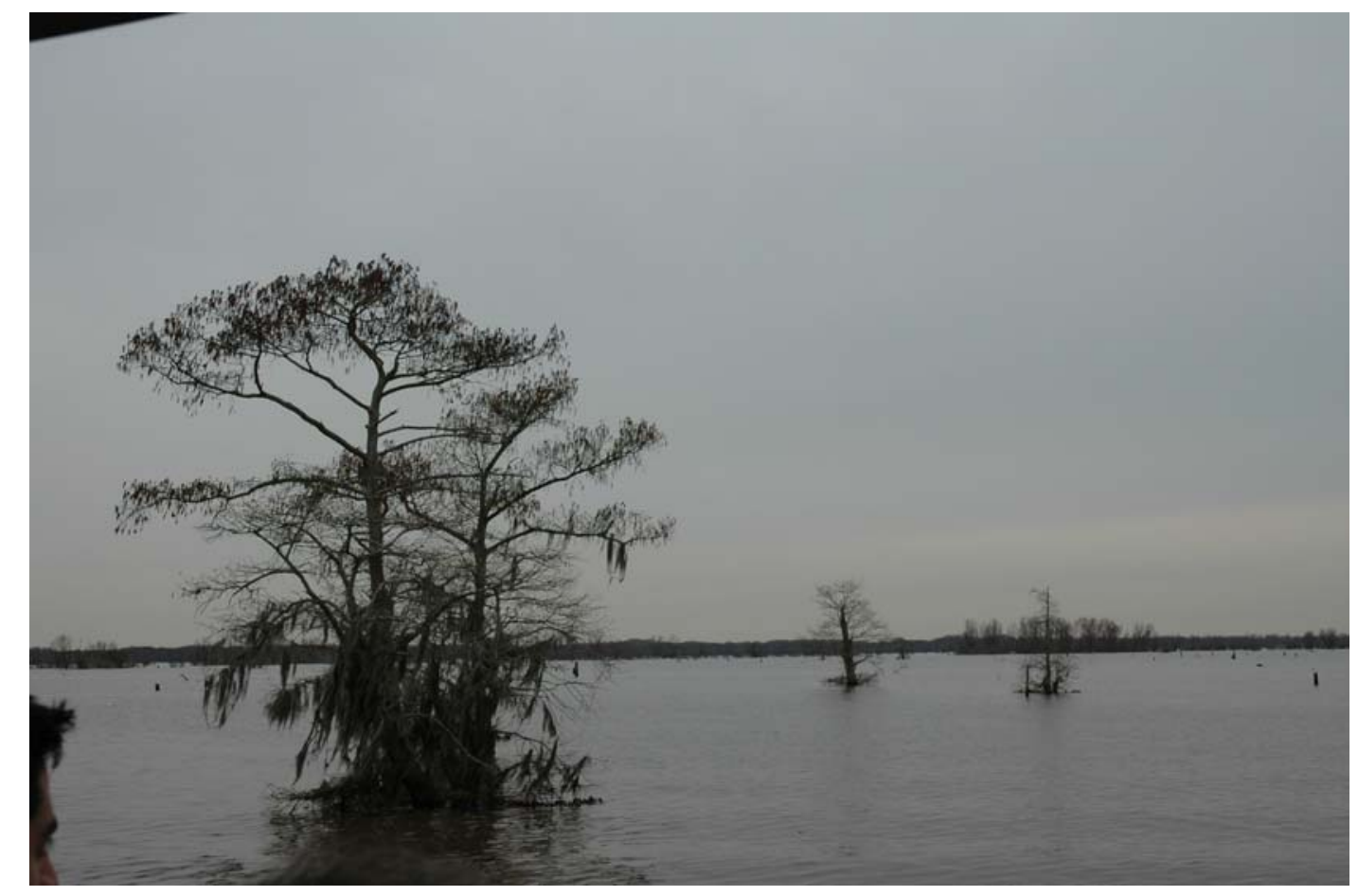

Figure 1. The detrimental effects of permanent impoundment are evident in this swamp, known locally as Henderson Swamp, in the Atchafalaya Basin Floodway of southern Louisiana.

\footnotetext{
${ }^{1}$ U.S. Geological Survey, National Wetlands Research Center, 700 Cajundome Boulevard, Lafayette, LA 70506
} 
Another reason that managers should avoid the permanent flooding of these forests is that production levels are lower in impounded situations than they are in natural swamps with flood pulsing (Broadfoot and Williston, 1973; Conner and others, 1981; Mitsch and others, 1991; Conner and Day, 1992; Megonigal and others, 1997; Conner and Buford, 1998; Watt and Golladay, 1999; Middleton and McKee, 2005). As primary production declines, the amount of material available to wildlife species also becomes lower, and a decline in the fishery or wildlife population may be detected about 10 years after impoundment (Young and Crew, 1982). During a study of impoundment in Illinois, production was reduced from 1992 to 1998 in the permanently flooded parts of Buttonland Swamp (a National Natural Landmark) by about onehalf, although it is not known what the minimum level of production is before trees begin to die (Middleton and McKee, 2005). The regeneration of trees was limited to the margins of the swamp because trees can only germinate and establish in drawn down conditions (Middleton 1999, 2000).

Wildlife production is also reduced by swamp impoundment. For example, a dam was constructed to improve sport fishing in Dead Lake along the Chipola River in Florida. Fishing increased for a time after the construction of the impoundment, but then fish populations began to decrease after 10 years (Young and Crew, 1982). Consequently, the dam was removed and the fishing and water quality improved (Hill and Hardin, 1993).

From a management perspective, any impoundment developed for for fisheries or wildlife purposes needs a drawdown for periods of time during the summer growing season. In cases where drawdown is reestablished after 1 year (but not more than 5 years), species such as baldcypress trees recover rapidly (Duever and McCollom, 1986). Tree regeneration of baldcypress also may occur (Keeland and Conner, 1999) in the presence of a seed bank (Middleton, 2003). The effects of impoundment seem particularly severe in the South (Middleton and McKee, 2005), so managers should take care to include at least a short period of drawdown during the summer growing season, especially in southern swamps. Managers should create impoundments in baldcypress swamps judiciously and recognize that swamps can not tolerate permanent inundation.

\section{References Cited}

Broadfoot, W.M., and Williston, H.L., 1973, Flooding effects on southern forests: Journal of Forestry, v. 71, p. 584 - 587.

Conner, W.H., Gosselink, J.G., and Parrondo, R.T., 1981, Comparison of the vegetation of three Louisiana swamp sites with different flooding regimes: American Journal of Botany, v. 68, p. 320 - 331.

Conner, W.H., and Day, J.W., Jr., 1989, Response of coastal wetland forest to human and natural changes in environment with emphasis on hydrology, in Hook, D.D., and Lea, R., eds. Proceedings of the Symposium, The Forested Wetlands of the Southern United States, June 12 - 14, 1988, Orlando, Florida: Chapel Hill, NC, North Carolina University Press, p. 34 - 43.

Conner, W.H., and Day, J.W., Jr., 1992, Water level variability and litterfall productivity of forested freshwater wetlands in Louisiana: American Midland Naturalist, v. 128, p. 237 245.

Conner, W.H., and Buford, M.A., 1998, Southern deepwater swamps, in Messina, M.G., and Conner, W.H., eds., Southern forested wetlands: Boca Raton, Fla., CRC Press, p. 261287. 
Duever, M.J., and McCollom, J.M., 1986, Cypress tree-ring analysis in relation to wetlands and hydrology, in Proceedings of the International Symposium on Ecological Aspects of Tree-ring Analysis, August 17 - 21, 1986, Marymount College, Tarrytown, New York: Washington, D.C., U.S. Department of Energy, pp. 249-260.

Eggler, W.A., and Moore, W.C., 1961, The vegetation of Lake Chicot, Louisiana, after eighteen years of impoundment: Southwestern Naturalist, v. 6, p. 175 - 183.

Harms, W.R., Schreuder, H.T., Hook, D.D., Brown, C.L., and Shropshire, F.W., 1990. The effects of flooding on the swamp forest in Lake Ocklawaha, Florida: Ecology, v. 61, p. 1412 - 1421.

Heitmeyer, M.E., Fredrickson, L.H., and Krause, G.F., 1989, Water and habitat dynamics of the Mingo Swamp in southeastern Missouri, Fish and Wildlife Research 67: Washington, D.C., U.S. Department of the Interior, 33 p.

Hill, M.J., Long, E.A., and Hardin, S., 1993, Effects of dam removal on Dead Lake, Chipola River, Florida, Apalachicola River Watershed Investigations: Florida Game and Fresh Water Fish Commission, A Wallop-Breaux Project F-39-R, 12 p.

Keeland, B.D., and Conner, W.H., 1999, Natural regeneration and growth of Taxodium distichum (L.) Rich. in Lake Chicot, Louisiana after 44 years of flooding: Wetlands, v. 19, p. 149 - 155.

Klimas, C.V., 1987, Baldcypress response to increased water levels, Caddo Lake, LouisianaTexas: Wetlands, v. 7, p. 25 - 37.

Loftus, T.T., 1994, Status and assessment of Taxodium distichum (L.) Rich. and Nyssa aquatica L. in Horseshoe Lake. Alexander County, Illinois: Phase one - baseline study: Carbondale, Southern Illinois University, M.S. thesis.

Megonigal, J.P., Conner, W.H., Kroeger, S., and Sharitz, R.R., 1997, Aboveground production in southeastern floodplain forests: a test of the subsidy-stress hypothesis: Ecology, v. 78, p. 370-384.

Middleton, B.A., 1999, Wetland restoration, flood pulsing and disturbance dynamics: New York, John Wiley and Sons, $400 \mathrm{p}$.

Middleton, B.A., 2000, Hydrochory, seed banks, and regeneration dynamics across landscape boundaries in a forested wetland: Plant Ecology, v. 146, p. 169 - 184.

Middleton, B.A., 2003, Soil seed banks and the potential restoration of forested wetlands after farming: Journal of Applied Ecology, v. 40, p. 1025-1034.

Middleton, B.A., 2002, Flood pulsing in the regeneration and maintenance of species in riverine forested wetlands of the southeastern United States, in Middleton, B.A., ed., Flood pulsing in wetlands: restoring the natural hydrological balance: New York, John Wiley and Sons, p. 223 - 294.

Middleton, B.A., 2003, Soil seed banks and the potential restoration of forested wetlands after farming: Journal of Applied Ecology, v. 40, p. 1025 - 1034.

Middleton, B.A., and McKee, K.L., 2004, Use of a latitudinal gradient in bald cypress production to examine physiological controls on biotic boundaries and potential responses to environmental change: Global Ecology and Biogeography, v. 13, p. 247258.

Middleton, B.A., and McKee, K.L., 2005, Primary production in an impounded baldcypress swamp at the northern limit of the range: Wetlands Ecology and Management, v. 13, p. $15-24$. 
Mitsch, W.J., Taylor, J.R., and Benson, K.B., 1991, Estimating primary productivity of forested wetland communities in different hydrologic landscapes: Landscape Ecology, v. 5, p. 75 92.

Osment-DeLoach, J., and Moore, P., 1996, Brushy Lake mitigation bank site, in Proceedings, The Delta: Connecting Points of View for Sustainable Natural Resources, August 13 - 16, 1996, Memphis, TN: Lower Mississippi Valley Natural Resources Partnership and National Association of Conservation Districts, p. 297 - 301.

Penfound, W.T., 1949, Vegetation of Lake Chicot, Louisiana, in relation to wildlife resources: Proceedings of the Louisiana Academy of Science, v. 12, p. 47 - 56.

Yeager, L.E., 1949, Effect of permanent flooding in a river-bottom timber area, Illinois: Natural History Survey Bulletin, v. 25, p. 33 - 65.

Young, N., and Crew, J., 1981, Fish management report, northwest region: Annual Report to the Florida Game and Fresh Water Fish Commission, v. 3, p. 1 - 15.

Watt, K.M., and Golladay, S.W., 1999, Organic matter dynamics in seasonally inundated, forested wetlands of the Gulf Coastal Plain, Wetlands, v. 19, p. 139 - 148. 